\title{
Modelling the Role of SuDS Management Trains in Minimising Flood Risk, Using MicroDrainage
}

\author{
Craig Lashford ${ }^{1, *}$, Susanne Charlesworth ${ }^{1}\left[\right.$, Frank Warwick ${ }^{2}\left(\mathbb{D}\right.$ and Matthew Blackett ${ }^{1}$ \\ 1 Centre for Agroecology, Water \& Resilience, Coventry University, Coventry CV1 5FB, UK; \\ apx119@coventry.ac.uk (S.C.); aa8533@coventry.ac.uk (M.B.) \\ 2 School of Energy, Construction \& Environment, Coventry University, Coventry CV1 5FB, UK; \\ aa4510@coventry.ac.uk \\ * Correspondence: ab0874@coventry.ac.uk
}

Received: 6 August 2020; Accepted: 4 September 2020; Published: 13 September 2020

\begin{abstract}
This novel research models the impact that commonly used sustainable drainage systems (SuDS) have on runoff, and compare this to their land take. As land take is consistently cited as a key barrier to the wider implementation of SuDS, it is essential to understand the possible runoff reduction in relation to the area they take up. SuDS management trains consisting of different combinations of detention basins, green roofs, porous pavement and swales were designed in MicroDrainage. In this study, this is modelled against the 1\% Annual Exceedance Potential storm (over 30, 60, 90, 120, 360 and $720 \mathrm{~min}$, under different infiltration scenarios), to determine the possible runoff reduction of each device. Detention basins were consistently the most effective regarding maximum runoff reduction for the land they take $\left(0.419 \mathrm{~L} / \mathrm{s} / \mathrm{m}^{2}\right)$, with porous pavement the second most effective, achieving $0.145 \mathrm{~L} / \mathrm{s} / \mathrm{m}^{2}$. As both green roofs $(20.34 \%)$ and porous pavement $(6.76 \%)$ account for land that would traditionally be impermeable, there is no net-loss of land compared to a traditional drainage approach. Consequently, although the modelled SuDS management train accounts for $34.86 \%$ of the total site, just $7.76 \%$ of the land is lost to SuDS, whilst managing flooding for all modelled rainfall and infiltration scenarios.
\end{abstract}

Keywords: detention basins; green roofs; MicroDrainage; porous pavement; runoff reduction; swales

\section{Introduction}

\subsection{Sustainable Drainage Systems Management Train}

In an evolving environment, the risk of flooding is increased when conventional piped based systems are not adapted to manage the intensified stormwater runoff associated with both increased impermeable surfaces and a changing climate. Sustainable drainage systems (SuDS), however, provide an alternative approach to managing stormwater and flooding [1]. SuDS mimic natural hydrological processes which have been lost, due to urbanization and associated impermeable surfaces and the installation of pipe-based drainage [2]. Whilst the SuDS square emphasizes the equal importance of water quantity, water quality, amenity and biodiversity, regarding the likely benefits of integrating SuDS, in reality, water quantity or quality benefits are typically prioritized by drainage engineers [3]. A SuDS management or treatment train is a system which utilizes a range of SuDS devices in sequence to reduce flow and the overall level of pollution in runoff [4]. When focusing on water quality, combinations of SuDS devices are often termed treatment trains, however, the focus of the present study is on water quantity reduction, and therefore, the term "SuDS management train" will be used.

A SuDS management train provides extra levels of resilience against flooding, as more devices are used, resulting in greater levels of water retention [5]. It is not always feasible to utilize one large device 
at a site, therefore, a series of smaller linked devices in a management train can be more practical, meeting the requirements of the SuDS square. Past research has demonstrated the effectiveness with which a SuDS management train can reduce runoff, in comparison with conventional drainage, and in comparison to impermeable surfaces [6]. Limited research exists regarding which devices should be prioritized in a management train and how different devices work when combined, although susdrain [7] suggested that swales, detention basins, green roofs and porous pavement are amongst the most commonly used in England and Wales.

\subsection{Sustainable Drainage Management Trains: Barriers to Their Implementation}

Although research demonstrates the benefits of integrating SuDS, there has been a reluctance from stakeholders and practitioners in the UK to see SuDS implemented as an approach to more sustainable methods of drainage [8]. SuDS are a divergence from traditional pipe-based methods, encouraging the integration of more natural open water management in the built environment, and such a change in paradigm has resulted in resistance to their wider implementation [2].

The primary concern of developers typically relates to the design, integration and operational role of SuDS, with a perceived lack of clarity on the potential benefits that SuDS can bring [9,10]. Land use is a key barrier, particularly at new build sites where there is often an emphasis on maximizing profits by housebuilders and construction companies, and therefore, minimizing above-ground drainage space [8,11,12]. Maximizing space is equally critical when redesigning urban areas and as such, ensuring the most effective SuDS devices are identified is vital [13]. The innovative research presented here incorporates a management train approach in demonstrating how effective different SuDS approaches can be, in terms of their impact on runoff and their footprint, and how beneficial SuDS can be for flood risk management. UK flooding in winter 2015/2016 impacted 16,000 properties and caused GBP 1.3 billion damage; given the UK Government's commitment to building 300,000 new homes a year until 2023, SuDS offer a sustainable approach to future flood management, particularly in a changing climate [14]. Climate change is expected to increase annual rates of rainfall, as well as both intensity and frequency of large rainfall events, particularly during winter [15]. Consequently, the annual cost of flooding in the UK is expected to rise under the $2 \mathrm{deg}$ warming scenario by $54 \%$ by 2080 , with $40 \%$ more properties likely to be impacted by flooding by 2080 , even with the assumption that population remains static [16].

To demonstrate the benefits, and promote the wider integration of SuDS into UK drainage design, this research focuses on the water quantity benefits of different SuDS techniques, and their benefits in relation to land-take, particularly when combined in a management train. The project compares the benefits of SuDS installations to the associated loss of land, focusing on two key areas of resistance: Peak runoff reduction and land take. Whilst much of the research focuses on new-build developments, the prioritization of space and the impact by area and volume of different devices is pertinent for retrofit installations; previous studies have not standardized the impact on runoff of different linked devices by area $\left(\mathrm{m}^{2}\right)$ and volume $\left(\mathrm{m}^{3}\right)$ [17]. This research provides an assessment of the most commonly used SuDS in the UK and how effectively they reduce runoff in relation to the amount of land take.

\section{Methods}

\section{Analysis of Sustainable Drainage Systems in a Management Train}

This study uses the UK industry standard drainage model, MicroDrainage v2019.1 [18], and adapts the method from Lashford et al. [6], which determined the overall modelled runoff reduction of using SuDS management trains. The research framework for this study is presented in Figure 1. This research further assesses each device regarding the space they account for in the model. A SuDS management train was developed using the DrawNet tool, with LiDAR data with a $1 \mathrm{~m}^{2}$ vertical resolution used to determine flood flow routes (Figure 1). Therefore, a site was designed based nominally on an existing 5 ha new build development with 250 proposed houses, in Coventry, UK (Figure 2). The SuDS 
devices used in this study are presented in Table 2, and constitute the most commonly used devices in management trains in England and Wales, based on an analysis of the susdrain [7] database, with the designed layout based on existing SuDS management trains in Hamilton, Leicester, UK and Upton, Northampton, UK [3]. The area and volume presented in Table 2 were calculated based on the overall site design. Although the focus of the findings is on the total area $\left(\mathrm{m}^{2}\right)$, as space is defined as a key barrier to the uptake of SuDS, to understand the characteristics of the SuDS used, the total storage volume $\left(\mathrm{m}^{3}\right)$ is also provided (Figure 1) [8-10].

Table 1. Different combinations of each SuDS device in the modelled management trains.

Devices Used
Swale
Green roof and swale
Porous pavement and swale
Green roof, porous pavement and swaleSwale and detention basin
Green roof, swale and detention basin
Porous pavement, swale and detention basin
Green roof, porous pavement, swale and detention basin

Table 2. Total area, \% of the total land take and volume of each SuDS device used in the analysis.

\begin{tabular}{cccc}
\hline Device & Total Area $\left.\mathbf{( m}^{\mathbf{2}}\right)$ & \% of Total Land Take & Total Volume $\mathbf{( m}^{\mathbf{3}} \mathbf{)}$ \\
\hline Detention basin & 2189 & 4.38 & 4658 \\
Green roof & 10,170 & 20.34 & 1017 \\
Porous Pavement & 3380 & 6.76 & 1568 \\
Swale & 1692 & 3.38 & 1322 \\
\hline
\end{tabular}

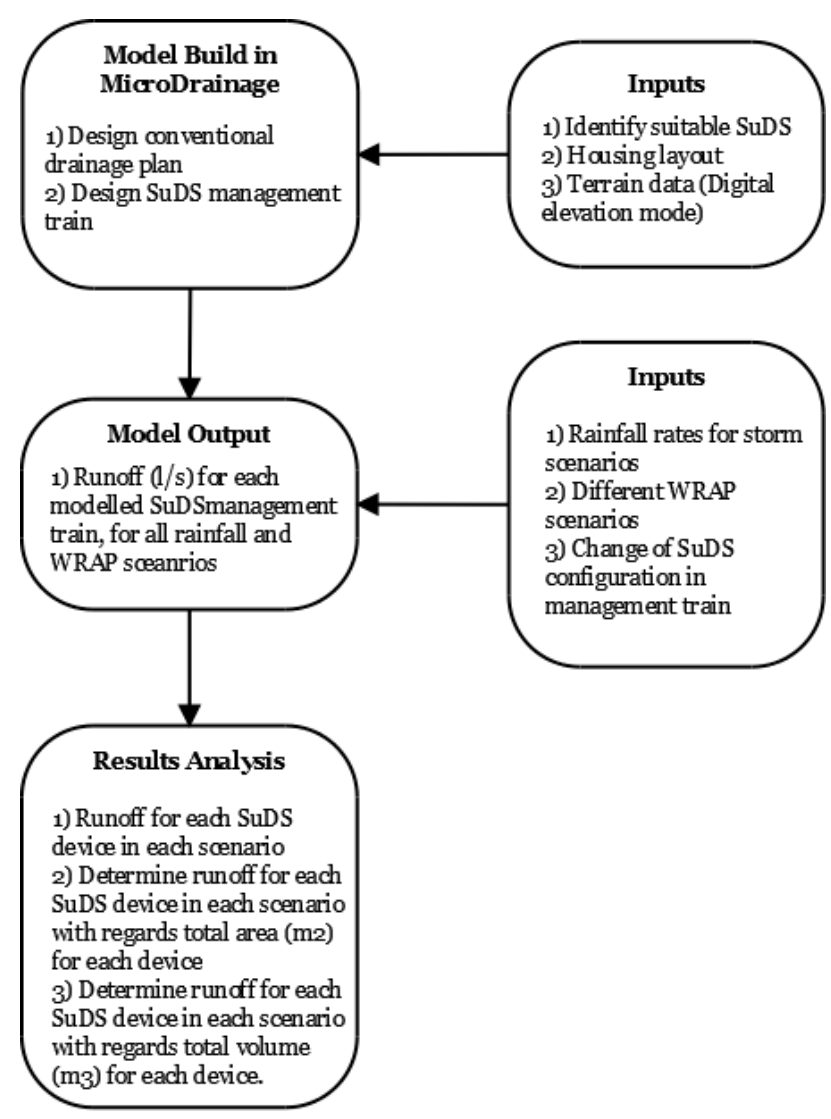

Figure 1. The research framework for the project. 


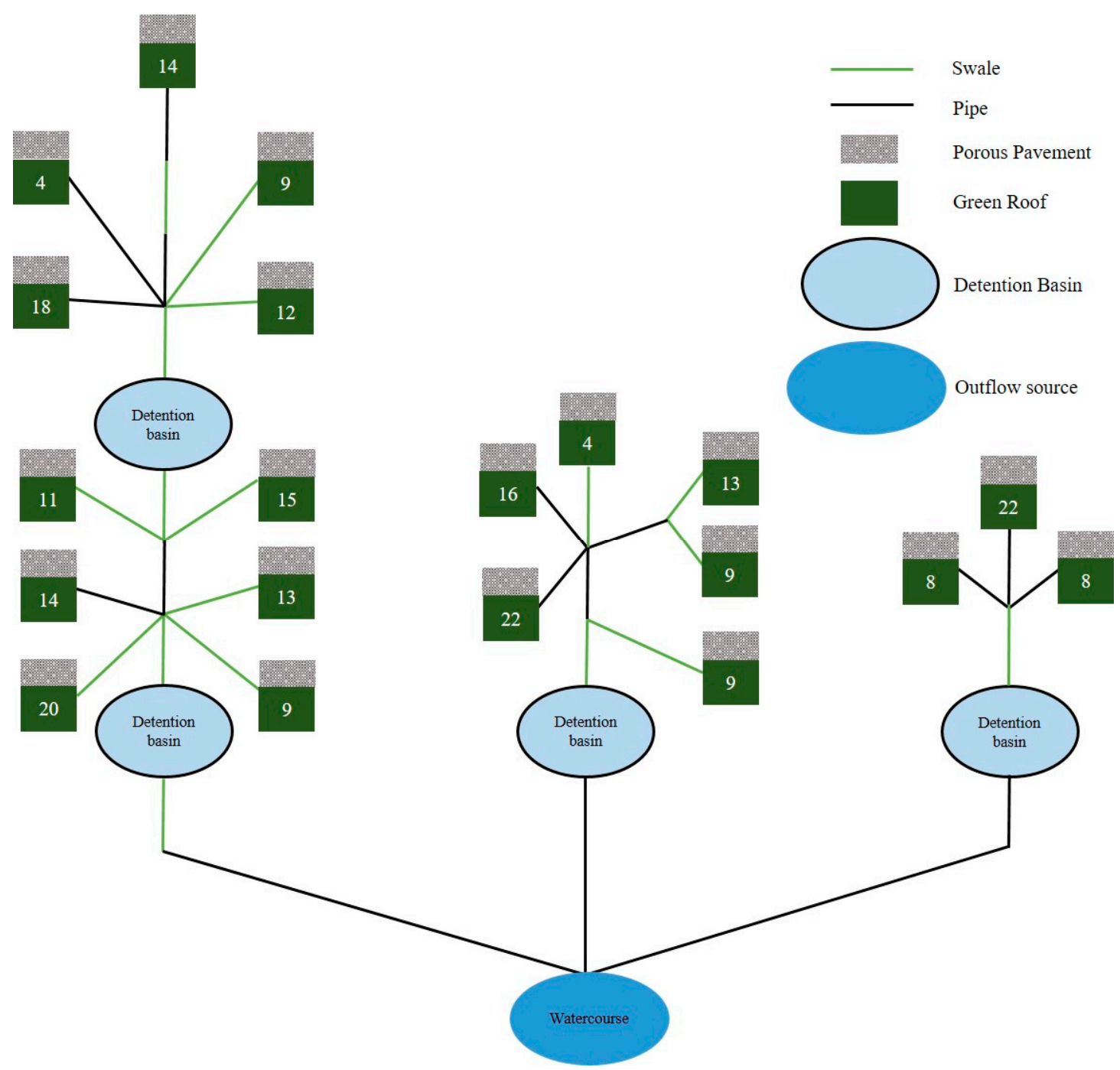

Figure 2. Schematic layout of the SuDS management train, not to scale. If a SuDS device was not included in the model (Table 1), they were bypassed. The number indicates the total number of houses at the site.

The modelled porous pavement, which were integrated on the driveway for each house, had an infiltration coefficient consistent with overall site infiltration, and therefore, varied dependent on the winter rainfall acceptance potential (WRAP) value. MicroDrainage uses the WRAP method to quantify infiltration and standard percentage runoff and was developed in the Flood Studies Report categorizing soil based on soil water regime, depth to an impermeable layer, the permeability of soil horizons and slope of land [19-21]. To ensure the wider applicability of the findings, the WRAP of 0.5 (low infiltration) 0.3 (medium infiltration) 0.15 (high infiltration) were used. The porosity of each device was 0.3 , as suggested by Woods Ballard et al. [3], with a maximum membrane percolation of $1000 \mathrm{~mm} \mathrm{~h}^{-1}$ and a total depth of $450 \mathrm{~mm}$, in line with British Standard Institution [22] specifications. The green roofs were designed on each of the 250 houses, with $5 \mathrm{~mm}$ depression storage, an overall depth of $100 \mathrm{~mm}$ and a decay coefficiency 0.05 , as recommended by Stovin [23]. The governing equation for flow through the green roof is based on the assumption made by XP Solutions that the roof will become saturated at $120 \mathrm{~min}$, regardless of rainfall intensity. Swales were designed with a Manning's value of 0.06, in accordance with Chow [24], and were designed to run alongside the proposed pavement structure, ranging from a width of $600 \mathrm{~mm}$ to $3000 \mathrm{~mm}$, when space was available (Figure 2). Wider swales were used in this study away from the roadside, when conveying flow from 
detention basins. Designing swales alongside pavements reduces the amount of open space that the SuDS devices occupy [17]. For safety reasons swales, had a 1:3 side slope, which limited gradient [3].

$$
A_{t}=e^{-k t}, a_{t}=\left(\frac{A_{t}}{\sum A_{t}}\right) a
$$

where $a$ is the total area of the green roof, $A$ is a factor required to scale the curve to provide the correct total catchment area, $e$ is the exponential, $k$ is the decay coefficiency and $t$ is time in min.

All source control devices were channelled into detention basins via swales or pipes. Pipes were used whenever open-channel flow was not possible, for example, when water was conveyed below a road (Figure 2). Once runoff from a source control device was collected in a detention basin, it was conveyed to a nearby watercourse. Swales were used in all scenarios to convey runoff. The impact of each device was compared with the total land take $\left(\mathrm{m}^{2}\right)$ and storage volume of each SuDS device $\left(\mathrm{m}^{3}\right)$ to determine the most space-effective design for the maximum and minimum achieved reduction of peak flow, dependent on the combined devices.

The different modelled management trains are highlighted in Table 1. Each combination was modelled for the $0.5,0.3$ and 0.15 WRAP values, with the overall site assigned a consistent WRAP value, apart from the impermeable surfaces, such as roads and pavements. The model was also run under differing rainfall durations, to understand the response to a range of rainfall intensities. The UK Non Statutory-Standards for SuDS require sites to be designed to deal with runoff for the $1 \%$ Annual Exceedance Potential (AEP) $360 \mathrm{~min}(11.92 \mathrm{~mm} / \mathrm{h})$ storm, therefore, this rainfall scenario was used in this research [25]. However, to demonstrate the effectiveness of devices to a variety of storm intensities, the $1 \%$ AEP $30 \min (73.14 \mathrm{~mm} / \mathrm{h}), 60 \mathrm{~min}(44.09 \mathrm{~mm} / \mathrm{h}), 90 \min (32.79 \mathrm{~mm} / \mathrm{h}), 120 \min (26.58 \mathrm{~mm} / \mathrm{h})$ and $720 \mathrm{~min}(7.18 \mathrm{~mm} / \mathrm{h})$ duration storms were also simulated.

\section{Results}

Figures 3-5 present the impact for each of the four modelled devices, dependent on the WRAP infiltration scenario and rainfall duration, based on the range of possible peak flow reduction (Figure 3a-d), the impact the device has in relation to area $\left(\mathrm{L} / \mathrm{s} / \mathrm{m}^{2}\right.$ ) (Figure $4 \mathrm{a}-\mathrm{d}$ ) and volume $\left(\mathrm{L} / \mathrm{s} / \mathrm{m}^{3}\right.$ ) (Figure 5a-d). Based on this modelling, maximum runoff reduction in comparison with conventional piped drainage was achieved for all SuDS components when used just in conjunction with swales (and for swales alone), for example, detention basins and swales. Figure 3a shows that detention basins, as part of the management train, consistently reduced maximum peak runoff $(\mathrm{L} / \mathrm{s})$ under all infiltration and rainfall scenarios more than any other modelled SuDS technique. Figure 3a-d show that as rainfall intensity decreases, the total reduction in runoff decreases. Furthermore, for all scenarios, the maximum reduction is achieved during the WRAP 0.5 event. 


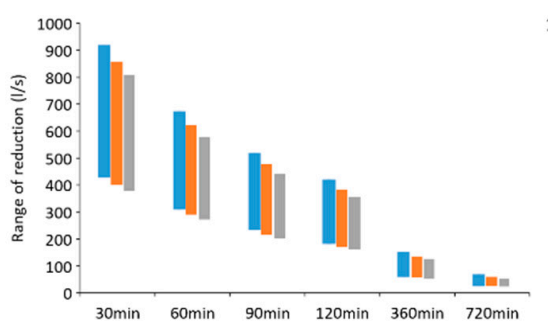

(a)

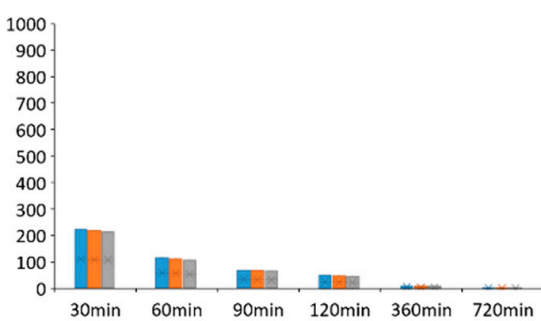

(b)

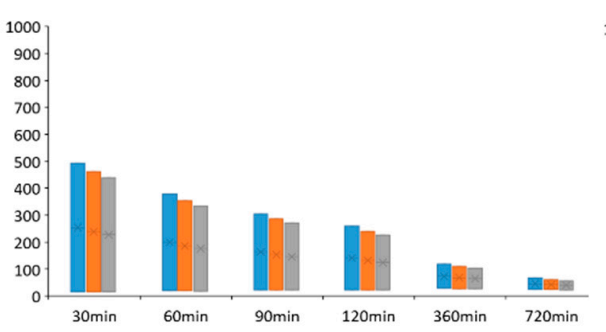

(c)

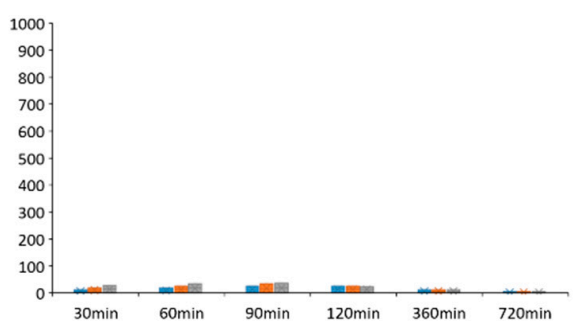

(d)

Figure 3. The maximum and minimum range of possible reduction of runoff (L/s) for each device; (a) Detention basins, (b) green roofs, (c) porous pavement (d) swales. Each color represents a different WRAP scenario. Blue 0.5, Orange 0.3 and Grey 0.15 .
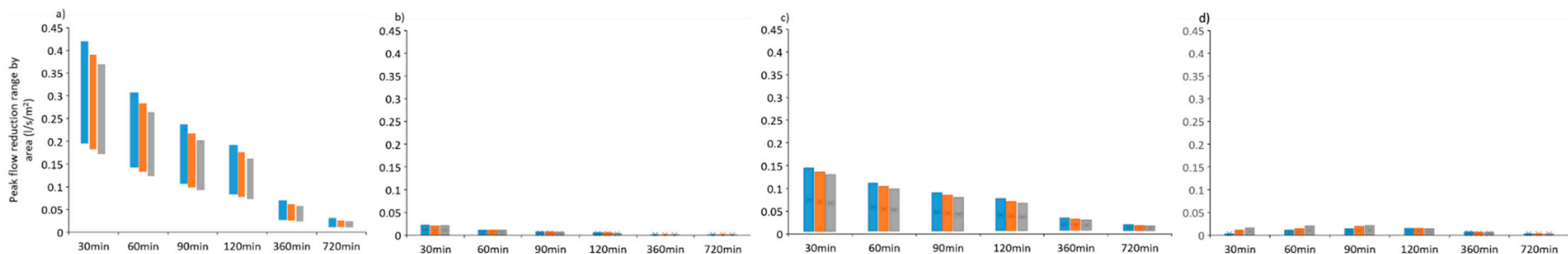

Figure 4. The maximum and minimum range of peak flow reduction by area $\left(\mathrm{L} / \mathrm{s} / \mathrm{m}^{2}\right)$ for each device; (a) Detention basins, (b) green roofs, (c) porous pavement (d) swales. Each color represents a different WRAP scenario. Blue 0.5, Orange 0.3 and Grey 0.15.
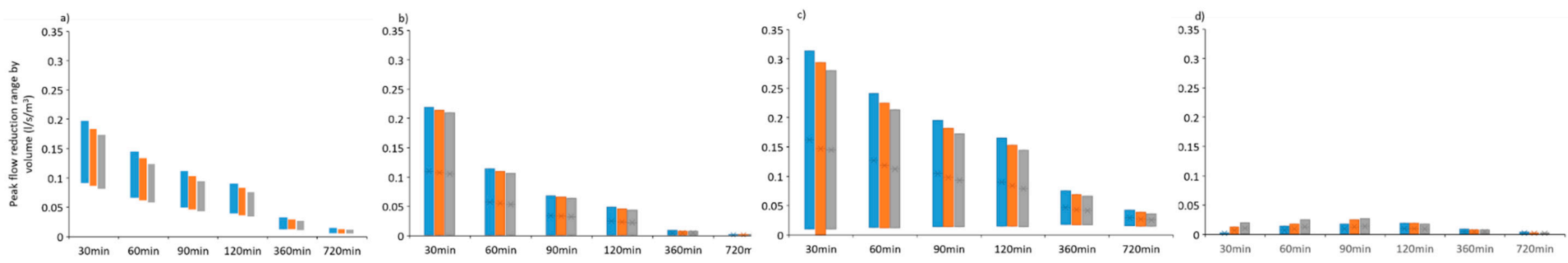

Figure 5. The maximum and minimum range of peak flow reduction by volume $\left(\mathrm{L} / \mathrm{s} / \mathrm{m}^{3}\right)$ for each device; (a) detention basins (b) green roofs (c) porous pavement (d) swales. Each color represents a different WRAP scenario. Blue 0.5, Orange 0.3 and Grey 0.15. 
Detention basins were the most effective device for all scenarios when analyzing the impact on the area, achieving a maximum reduction of $0.419 \mathrm{~L} / \mathrm{s} / \mathrm{m}^{2}$ for the $30 \mathrm{~min}$ storm under 0.5 WRAP infiltration conditions (Figure 4a). Conversely, Figure 5a shows that detention basins are less effective at reducing runoff, compared to the other modelled devices, in relation to their volume $\left(\mathrm{L} / \mathrm{s} / \mathrm{m}^{3}\right)$. This is likely due to their greater capacity to store water and increased total volume (Table 2).

The second consistently most effective device was porous pavement, which achieved a reduction of $0.145 \mathrm{~L} / \mathrm{s} / \mathrm{m}^{2}$ for $30 \mathrm{~min}, 0.5 \mathrm{WRAP}$ scenario (Figure 4c). However, when accounting for the total volume of the device $\left(\mathrm{L} / \mathrm{s} / \mathrm{m}^{3}\right)$, porous pavement outperformed the other modelled devices for all scenarios (Figure 5a-d). Although the modelled porous pavement covered $1191 \mathrm{~m}^{2}$ (2.54\% more) more total land than detention basins, they had a significantly reduced total volume $\left(3090 \mathrm{~m}^{3}\right.$ less) than the modelled detention basins, accounting for the switch in performance depending on whether area or volume was analyzed (Table 2).

The additional source management device modelled was the green roof, which had little effect on reducing peak flow in comparison to the porous pavement for all rainfall durations greater than $120 \mathrm{~min}$. The greatest peak flow reduction that was achieved for rainfall duration longer than $120 \mathrm{~min}$, when adding green roofs to the swale management train, was $9 \mathrm{~L} / \mathrm{s}$, for the $360 \mathrm{~min} 0.5$ WRAP model (Figure $3 b$ ), resulting in consistently less than $0.001 \mathrm{~L} / \mathrm{s} / \mathrm{m}^{2}$ (Figure $4 \mathrm{~b}$ ) in relation to the area covered. However, the equation used in MicroDrainage that dictates flow in a green roof is based on a saturation capacity being reached at $120 \mathrm{~min}$ (see Equation (1)). The influence of the equation is evident in the runoff reduction for events up to and including $120 \mathrm{~min}$ (Figure 3b), where the performance of green roofs is greatly improved in comparison to the longer duration events. Consequently, their impact on reducing runoff decreased as storm intensity decreased, due to their significantly reduced storage capacity in comparison to other modelled SuDS techniques (at least $305 \mathrm{~m}^{3}$ less total volume). Therefore, for each rainfall scenario up to and including the 120 min duration, green roofs outperformed swales, and for the intense $30 \mathrm{~min}$ storm, outperformed detention basins regarding peak reduction by total volume $\left(\mathrm{L} / \mathrm{s} / \mathrm{m}^{3}\right)$ (Figure 5). Swales were marginally more effective than green roofs, based on area utilized in the model design, for all storm durations over $60 \mathrm{~min}$ (Figure 4). Nevertheless, the influence of swales to reduce runoff remained limited for all scenarios; with a peak runoff reduction of $35.2 \mathrm{~L} / \mathrm{s}$ occurring for the $90 \mathrm{~min}$ duration storm, $0.15 \mathrm{WRAP}$ model, compared to $65 \mathrm{~L} / \mathrm{s}$ runoff reduction for the same model configuration for green roofs (Figure 3).

Figures 3-5 show that when comparing infiltration scenarios and rainfall intensities, there is little modelled change for the role of the most effective devices; detention basins were consistently the most effective in terms of area and porous pavement in terms of volume, regardless of the $120 \mathrm{~min}$ delay in saturation for green roofs. The maximum reduction in peak flow for each device decreased as infiltration increased, apart from swales (Figures $3 \mathrm{~d}, 4 \mathrm{~d}$ and $5 \mathrm{~d}$ ). For detention basins, green roofs and porous paving, this is likely a result of their reliance on storing stormwater and less runoff entering all SuDS devices, with a greater amount being infiltrated into the surrounding green space, reducing the impact of each SuDS technique. However, swales act differently; runoff reduction (L/s) increases as infiltration increases, up to the $90 \mathrm{~min}$ storm duration, and plateaus for the $120 \mathrm{~min}$ storm onwards, with no discernible reduction regardless of infiltration rates.

\section{Discussion}

The findings presented in Figures 3-5 show that SuDS can substantially reduce total site runoff, and ultimately reduce flooding. As identified previously, space is a critical factor in determining the wider implementation of SuDS, detention basins and porous pavement should, therefore, be prioritized when implementing SuDS as part of a management train [8-10]. This provides drainage engineers with guidance when developing new sites, but also regarding urban retrofit flood risk management, where space is a premium; which has also been identified as a barrier to the wider implementation of SuDS [11,12]. Both devices were consistently the most effective at reducing runoff in relation to their land-take, accounting for $4.38 \%$ and $6.78 \%$ (Table 2) of the total modelled site, respectively 
(Figures 3-5). Both detention basins and porous pavement encourage infiltration by storing large volumes of runoff during high-flow events, however, their effectiveness is largely constrained by site infiltration conditions, structure size, and in the case of porous pavement, void space and material used (as also document in Yazdi [26], and Scholz and Grabowiecki [27]).

Whilst detention basins were most effective in terms of their area, they account for $2189 \mathrm{~m}^{2}$ of space that could otherwise be used for housing, decreasing potential site profits; a typical barrier to their integration in drainage schemes [10]. Furthermore, 83\% of the population in England currently live in existing urban areas. With a likely rise of high-intensity rainfall events as a result of climate change, sustainable approaches to urban pluvial flood management are required [28]. Subsequently, integrating detention basins in an already densely populated space, where land is at a premium, is a challenge [29,30]. Figure 3a-d, however, demonstrate the reduction in runoff that can be achieved through including detention basins into urban design, and if designed effectively, can be successfully incorporated into both new build and retrofit sites. The UK has taken a risk-averse approach to open stormwater basins in cities, with few retrofit examples, preferring to install shallow, densely vegetated detention basins predominantly at new build sites, which are less multi-functional [9,31-33]. Nevertheless, there are successful international examples of integrating SuDS into urban design, for example, Malmo, Sweden and Portland, USA, where detention basins not only provide water quantity improvements, but retain multiple benefits, such as recreational space, when dry [34,35]. Although detention basins are not the entire solution to reducing overall flood risk, they present an opportunity for reducing local, pluvial flooding by storing large volumes of water [36]. Integrating above-ground visible strategies for flood alleviation, by developing SuDS management trains at site scale can also enhance community resilience to flooding, by increasing local understanding of flooding, and removing the traditional 'out of sight out of mind' mentality [37].

Porous pavement is used instead of traditional impermeable surfaces, and is often indistinguishable to the lay public [27]. In the model used for this research, porous pavement did not take up potential green space as it replaced existing driveways for each property. For this reason, regardless of the $6.76 \%$ total land take, there was no net-loss of land use, and there was a reduction of runoff when used in combination with other devices of up to $491.7 \mathrm{~L} / \mathrm{s}$, for the $30 \mathrm{~min}$ rainfall event (Figure 3c). Consequently, porous pavement is a suitable sustainable method of flood risk reduction, as it not only can reduce runoff, but also provides multiple uses, such as car parks and low traffic roads, increasing its amenity benefits [3]. However, the impact of porous pavement on runoff, when analyzed in terms of area, was consistently less than detention basins. This is a result of a greater modelled surface area for porous pavement, in comparison to detention basins, although the total below-ground storage capacity for detention basins was far greater (see Table 2). As detention basins were much deeper (1500 $\mathrm{mm}$ in comparison to a storage capacity of porous pavement of $450 \mathrm{~mm}$ ) than other devices modelled, the area occupied was relatively modest. Therefore, they were nearly twice as effective for an equivalent space as porous pavement. This is further demonstrated in the analysis regarding volume, and explains why porous pavement, which had nearly three times less total volume than detention basins, were consistently more effective at reducing peak flow by total volume. Analysis of both area and volume shows the need to prioritize porous pavement at the source control stage and detention basins as site control, in addressing runoff, supporting research by Chen et al. [38] and Woods Ballard et al. [3] who endorsed both as highly effective flood management tools. Whilst the modelled detention basins take up $6.76 \%$ of modelled land, which could be used for additional housing and is typically presented as a barrier to the wider implementation of SuDS, the possible benefit on reducing runoff is considerable [8-10]. Similar to detention basins, there has been a risk-averse approach to integrating porous pavement in cities in the UK, due to a lack of experience of their design and implementation, the associated costs of retrofitting porous pavement and the possible disruption pre and post-installation [33]. However, whilst the concerns exist, particularly surrounding the cost of porous pavement, research by Gordon-Walker et al. [39] shows that there are cost benefits for using the device for runoff management. Furthermore, this research has demonstrated the scale of runoff 
reduction that can be achieved by utilizing porous pavement in the SuDS management train as an alternative to impermeable surfaces.

The other modelled source control device were green roofs, which has a relatively limited impact on reducing runoff in MicroDrainage, particularly as the modelled storm duration increases (Figure 3b). As green roofs have only a small storage depth of $100 \mathrm{~mm}$, as suggested by Stovin [23], compared to the larger storage capabilities of detention basins and porous pavement, the effectiveness of green roofs is lower. However, the governing Equation (1) for flow in a green roof in MicroDrainage is based on the assumption that it reaches saturation at $120 \mathrm{~min}$, regardless of total rainfall depth. Such an arbitrary storage capacity is an unrealistic representation of a green roof structure. Figure $3 \mathrm{~b}$ shows that the green roof model reduces peak flow most effectively for the highest intensity $30 \mathrm{~min}$ storm $(73.14 \mathrm{~mm} / \mathrm{h})$, with a reducing impact as intensity decreases. This is a result of Equation (1) in the model, which results in near total water storage in a green roof, regardless of the rainfall intensity. Using physical models, Stovin et al. [40], demonstrated that green roofs act entirely differently to the MicroDrainage model, with peak performance and runoff reduction achieved during low-intensity events, their abilities reducing as intensity increases. As green roofs are often sloped, their ability to retain water, particularly during high-intensity rainfall is restricted [23]. Whilst specific vegetation on a roof, if extensive, can slow down runoff, increasing infiltration, the influence of slope can considerably reduce the effectiveness of a green roof [41]. Nonetheless, all models show that green roofs are capable of reducing runoff, with varying levels of success, which is similar to the findings of De Ville et al. [42]. Therefore, while green roofs have limited potential in this example on reducing runoff, they still provide extra resilience to further increase the impact of a SuDS management train, according to MicroDrainage, in small events. Green roofs also have multiple benefits by greatly increasing the amenity and biodiversity potential of a site and are capable of cooling urban areas, reducing the impact of the urban heat island effect and providing carbon sequestration $[43,44]$. For these reasons, site requirements must be assessed to better understand the suitability of green roofs in site design. Green roofs can be considered at new build sites during the early phases of design, with buildings appropriately designed to accommodate the increased potential load.

Swales were capable of reducing runoff by up to $2.6 \mathrm{~L} / \mathrm{s}$ more than green roofs for all infiltration scenarios, for storms with a longer duration than $120 \mathrm{~min}$. However, as identified in Section 3, the performance of the modelled swales was in contrast to the other devices; their effectiveness increased as infiltration rates increased. Whilst the other modelled devices rely on storing water, with varying levels of success, swales are primarily used for conveying stormwater around a site [3]. The Manning's value used for swales was 0.06 , therefore, whilst flow speeds are likely to be reduced, with some level of detention and consequently infiltration occurring, particularly in comparison to traditional impermeable pipes, the total runoff reduction is negligible [45]. Winston et al. [46] suggest that swales effectiveness for moderate scale events can be greatly improved by integrating check dams to further limit runoff and increase storage of stormwater. Additionally, their effectiveness is limited by the infiltration rate of a site, which corresponds with the modelled results for the higher intensity events $[47,48]$. The reduction in runoff for the two lowest intensity rainfall events (360 and $720 \mathrm{~min}$ ) was negligible, ranging from a maximum of $1.3 \mathrm{~L} / \mathrm{s}$ to $0.1 \mathrm{~L} / \mathrm{s}$. Therefore, the lack of storage in the modelled swales reduced their effectiveness, with limited runoff leaving the system through infiltration, in comparison with storing large volumes of water and allowing for slow infiltration, as occurs with the other modelled SuDS techniques [3]. Consequently, as infiltration increased, a slight increase in runoff reduction was achieved for the modelled swales during higher flows associated with more intense storms. Nonetheless, although they had a reduced capacity for detaining runoff, they are a critical component in a SuDS management train [49]. Swales provide open-channel conveyance of runoff in a SuDS management train, which is a more sustainable approach to traditional piped drainage. If designed effectively, for example, as roadside verges, swales enable conveyance of runoff, while also increasing the amenity and biodiversity of a site compared to impermeable surfaces $[3,50]$. 
Overall, the SuDS management train is capable of reducing runoff for all modelled rainfall scenarios and at each modelled infiltration type, with a total of $34.86 \%$ of the land being attributed to SuDS. It should, however, be noted that the rainfall scenarios modelled were for the $1 \%$ AEP storms, as suggested by UK drainage standards and current practice [25]. Consequently, this does not cover the most extreme scenarios, such as 2015 UK storm Desmond, which was calculated to be a $0.1 \%$ AEP storm, and also those occurring from a changing climate, which is more likely to cause catastrophic scale flooding [51]. Ellis and Viavattene [52] suggested that during the most extreme rainfall events, SuDS are capable of reducing the scale of the flooding, but are unlikely to fully manage all stormwater, as is the case with the design used for this research and the 1\% AEP scenario. However, as previously identified, there is long-held concern regarding the site benefits that can be achieved by integrating SuDS into the drainage scheme, with resistance often as a result of their high land-take [8-10]. The modelled SuDS management train had a net-land take of $7.76 \%$, which could be used for alternative use, if SuDS were not integrated. This is a result of both green roofs $(20.34 \%)$ and porous pavement $(6.76 \%)$ being constructed on space that would otherwise be impermeable surfaces, in traditional tiled roofs or impermeable driveways [12]. There are also wider benefits that can be achieved through integrating SuDS, as demonstrated by the SuDS Square, however, focusing on water quantity reductions, simply integrating swales across $3.38 \%$ of a site will achieve some reductions in total outflow, with further reductions seen as additional devices are added [3].

\section{Conclusions}

Whilst research has shown the benefits of integrating SuDS, particularly in a management train, there remain a number of barriers to their wider implementation [6]. This study has presented a novel approach to understand the specific benefits that popular SuDS techniques can have on minimizing peak runoffs, utilizing the UK industry standard drainage modelling tool, MicroDrainage. The results eliminate some of the long-held assumptions regarding the effectiveness of SuDS, and highlight the possible reduction in peak runoff that can be achieved by combining devices, with respect to their land-take. Figures 3-5 show the benefits of installing porous pavement at source control level, and detention basins at the site level, and whilst they take up a combined total of $11.14 \%$ of the total modelled site, they retain multiple additional benefits; detention basins can be used for recreational use, and porous pavement can replace existing impermeable surfaces [34,35]. Figure $3 \mathrm{~d}$ shows that the modelled swales responded differently to changing infiltration rates, compared to other modelled SuDS. As swales are primarily used for conveying stormwater, they are less effective than other techniques as they have a reduced capacity for storage. Consequently, they rely on infiltration rates as their sole method for reducing a limited amount of runoff, therefore, respond differently to the other modelled SuDS.

This study has also highlighted the challenges of using green roofs in MicroDrainage. The underlying Equation (1) for the tool is based upon an assumption that green roofs become saturated after $120 \mathrm{~min}$, and are capable with managing all rainfall up to that duration; therefore, their impact on reducing runoff is far greater for a shorter duration, higher intensity events. This is in contrast to findings by Stovin et al. [40]. It is suggested that whilst it is evident from all scenarios that green roofs are capable of reducing peak runoff to some extent, it is unclear how effective they can be, based on the MicroDrainage model. Validation using physical models is, therefore, required to determine the overall effectiveness of green roofs in the model.

The results establish the capabilities of each of the modelled SuDS devices, reducing the barriers for their uptake by demonstrating the benefits that can be achieved when combined in a SuDS management train, based on the current UK design standards. However, the modelled system accounts for $34.86 \%$ of the total site, there is a net-loss of space, in comparison to a traditionally designed site that did not include SuDS, of $7.76 \%$. By carefully selecting the SuDS that are to be used, it is possible to considerably reduce total site outflow at both new build developments and in the existing urban environment, without compromising greatly on space. This investigation, however, has demonstrated the need for 
future research to better understand how such sites will respond to extreme rainfall events that are expected to be more common in a changing climate.

Author Contributions: Conceptualization, C.L., S.C.; methodology, C.L., F.W. and M.B.; modelling, C.L.; formal analysis, C.L., S.C., F.W. and M.B.; writing-original draft preparation, C.L., and S.C.; writing-review and editing, C.L., S.C., F.W. and M.B.; visualization, C.L., and M.B.; supervision, S.C., F.W. and M.B. All authors have read and agreed to the published version of the manuscript.

Funding: This research received no external funding.

Acknowledgments: The authors would like to thank Coventry University for funding the research, Innovyze for providing a student licence for MicroDrainage and BWB Consulting for technical support with MicroDrainage.

Conflicts of Interest: The authors declare no conflict of interest.

\section{References}

1. Dearden, R.A.; Price, S.J. A proposed decision-making framework for a national infiltration SuDS map. Manag. Environ. Qual. Int. J. 2012, 23, 478-485. [CrossRef]

2. Fletcher, T.D.; Shuster, W.D.; Hunt, W.F.; Ashley, R.; Butler, D.; Arthur, S.; Trowsdale, S.; Barraud, S.; Semádeni-Davies, A.; Bertrand-Krajewski, J.-L.; et al. SUDS, LID, BMPs, WSUD and more-The evolution and application of terminology surrounding urban drainage. Urban Water J. 2014, 12, 525-542. [CrossRef]

3. Ballard, B.W.; Wilson, S.; Udale-Clarke, H.; Illman, S.; Scott, T.; Ashley, R.; Kellagher, R. The SuDS Manual (C753) 2015; CIRIA: London, UK, 2015.

4. Jefferies, C.; Duffy, A.; Berwick, N.; McLean, N.; Hemingway, A. Sustainable Urban Drainage Systems (SUDS) treatment train assessment tool. Water Sci. Technol. 2009, 60, 1233-1240. [CrossRef]

5. O'Sullivan, J.; Bruen, M.; Purcell, P.J.; Gebre, F. Urban drainage in Ireland-Embracing sustainable systems. Water Environ. J. 2011, 26, 241-251. [CrossRef]

6. Lashford, C.; Charlesworth, S.; Warwick, F.; Blackett, M. Deconstructing the sustainable drainage management train in terms of water quantity-Preliminary results for Coventry, UK. CLEAN Soil Air Water 2014, 42, 187-192. [CrossRef]

7. Susdrain. Available online: https://www.susdrain.org/case-studies/ (accessed on 2 February 2020).

8. Melville-Shreeve, P.; Cotterill, S.; Grant, L.; Arahuetes, A.; Stovin, V.; Farmani, R.; Butler, D. State of SuDS delivery in the United Kingdom. Water Environ. J. 2017, 32, 9-16. [CrossRef]

9. O’Donnell, E.C.; Lamond, J.E.; Thorne, C.R. Recognising barriers to implementation of Blue-Green Infrastructure: A Newcastle case study. Urban Water J. 2017, 14, 964-971. [CrossRef]

10. Booth, C.; Charlesworth, S. An overture of sustainable surface water management. In Sustainable Surface Water Management Systems: A Handbook for SuDS, 1st ed.; Charlesworth, S., Booth, C., Eds.; Wiley Blackwell: London, UK, 2016; Chapter 1; pp. 3-10.

11. Wade, R.; McLean, N. Multiple benefits of green infrastructure. In Water Resources in the Built Environment: A Handbook for SuDS, 1st ed.; Charlesworth, S., Booth, C., Eds.; Wiley Blackwell: London, UK, 2016; Chapter 24; pp. 319-335.

12. Jones, P.; Macdonald, N. Making space for unruly water: Sustainable drainage systems and the disciplining of surface runoff. Geoforum 2007, 38, 534-544. [CrossRef]

13. Stovin, V.; Moore, S.L.; Wall, M.; Ashley, R.M. The potential to retrofit sustainable drainage systems to address combined sewer overflow discharges in the Thames Tideway catchment. Water Environ. J. 2012, 27, 216-228. [CrossRef]

14. Ministry of Housing, Communities \& Local Government. Planning for the Future. 2020. Available online: https://assets.publishing.service.gov.uk/government/uploads/system/uploads/attachment_data/fil e/872091/Planning_for_the_Future.pdf (accessed on 5 June 2020).

15. Lowe, J.A.; Bernie, D.; Bett, P.; Bricheno, L.; Brown, S.; Calvert, D.; Clark, R.; Eagle, K.; Edwards, T.; Fosser, G.; et al. UKCP18 Science Overview Report. 2018. Available online: https://www.metoffice.gov.uk/pub/data/we ather/uk/ukcp18/science-reports/UKCP18-Overview-report.pdf (accessed on 30 August 2020).

16. Sayers, P.; Horritt, M.; Penning-Rowsell, E.; McKenzie, A. Climate Change Risk Assessment 2017 Projections of future flood risk in the UK. 2015. Available online: https://www.theccc.org.uk/wp-content/uploads/2015/ 10/CCRA-Future-Flooding-Main-Report-Final-06Oct2015.pdf.pdf (accessed on 30 August 2020). 
17. Bastien, N.; Arthur, S.; Wallis, S.; Scholz, M. The best management of SuDS treatment trains: A holistic approach. Water Sci. Technol. 2010, 61, 263-272. [CrossRef]

18. Innovyze. MicroDrainage v2019.1; Innovyze: Newbury, UK, 2019.

19. Kellagher, R. Preliminary Rainfall Runoff Management for Developments Report SC030219; Environment Agency: Bristol, UK, 2013.

20. Boorman, D.B.; Hollis, J.M.; Lilly, A. Hydrology of Soil Types: A Hydrologically Based Classification of the Soils of the United Kingdom; IH Report No. 126; Institute of Hydrology: Wallingford, UK, 1995.

21. Natural Environment Research Council. Flood Studies Report; NERC: London, UK, 1975.

22. British Standard Institution (BSI) BS7533-13:2009. Pavements Constructed with Clay, Natural Stone or Concrete Pavers; British Standards Institution: London, UK, 2009.

23. Stovin, V. The potential of green roofs to manage Urban Stormwater. Water Environ. J. 2009, 24, 192-199. [CrossRef]

24. Chow, V.T. Open-Channel Hydraulics; McGraw-Hill: New York, NY, USA, 1959.

25. Department for Environment, Food and Rural Affairs. Non-Statutory Technical Standards for Sustainable Drainage Systems. 2015. Available online: https://www.gov.uk/government/uploads/system/uploads/attac hment_data/file/415773/sustainable-drainage-technical-standards.pdf (accessed on 3 February 2020).

26. Yazdi, J. Optimal operation of urban storm detention ponds for flood management. Water Resour. Manag. 2019, 33, 2109-2121. [CrossRef]

27. Scholz, M.; Grabowiecki, P. Review of permeable pavement systems. Build. Environ. 2007, 42, $3830-3836$. [CrossRef]

28. Office for National Statistics. Rural Population and Migration. 2020. Available online: https: //assets.publishing.service.gov.uk/government/uploads/system/uploads/attachment_data/file/862320 /Rural_population_and_migration_Jan_20.pdf (accessed on 16 April 2020).

29. Miró, A.; Hall, J.; Rae, M.; O’Brien, C.D. Links between ecological and human wealth in drainage ponds in a fast-expanding city, and proposals for design and management. Landsc. Urban Plan. 2018, 180, 93-102. [CrossRef]

30. Gaborit, E.; Muschalla, D.; Vallet, B.; Vanrolleghem, P.; Anctil, F. Improving the performance of stormwater detention basins by real-time control using rainfall forecasts. Urban Water J. 2013, 10, 230-246. [CrossRef]

31. Potter, K.; Vilcan, T. Managing urban flood resilience through the English planning system: Insights from the 'SuDS-face'. Philos. Trans. R. Soc. A Math. Phys. Eng. Sci. 2020, 378, 20190206. [CrossRef]

32. Fenner, R.A.; Andrew, R.F. Spatial evaluation of multiple benefits to encourage multi-functional design of sustainable drainage in blue-green cities. Water 2017, 9, 953. [CrossRef]

33. Ellis, J.B.; Lundy, L. Implementing sustainable drainage systems for urban surface water management within the regulatory framework in England and Wales. J. Environ. Manag. 2016, 183, 630-636. [CrossRef] [PubMed]

34. Wihlborg, M.; Sörensen, J.; Olsson, J.A. Assessment of barriers and drivers for implementation of blue-green solutions in Swedish municipalities. J. Environ. Manag. 2019, 233, 706-718. [CrossRef]

35. Backhaus, A.; Dam, T.; Jensen, M.B. Stormwater management challenges as revealed through a design experiment with professional landscape architects. Urban Water J. 2012, 9, 29-43. [CrossRef]

36. Tsavdaris, A.; Mitchell, S.; Williams, J.B. Computational fluid dynamics modelling of different detention pond configurations in the interest of sustainable flow regimes and gravity sedimentation potential. Water Environ. J. 2014, 29, 129-139. [CrossRef]

37. Miller, J.D.; Hutchins, M. The impacts of urbanisation and climate change on urban flooding and urban water quality: A review of the evidence concerning the United Kingdom. J. Hydrol. Reg. Stud. 2017, 12, 345-362. [CrossRef]

38. Chen, J.; Liu, Y.; Gitau, M.W.; Engel, B.A.; Flanagan, D.C.; Harbor, J.M. Evaluation of the effectiveness of green infrastructure on hydrology and water quality in a combined sewer overflow community. Sci. Total. Environ. 2019, 665, 69-79. [CrossRef] [PubMed]

39. Gordon-Walker, S.; Harle, T.; Naismith, I. Cost-Benefit of SUDS Retrofit in Urban Areas. 2007. Available online: https://assets.publishing.service.gov.uk/government/uploads/system/uploads/attachment_data/fil e/290993/scho0408bnxz-e-e.pdf (accessed on 3 February 2020).

40. Stovin, V.; Vesuviano, G.; Kasmin, H. The hydrological performance of a green roof test bed under UK climatic conditions. J. Hydrol. 2012, 414, 148-161. [CrossRef] 
41. Berndtsson, J.C. Green roof performance towards management of runoff water quantity and quality: A review. Ecol. Eng. 2010, 36, 351-360. [CrossRef]

42. De-Ville, S.; Menon, M.; Jia, X.; Reed, G.; Stovin, V. The impact of green roof ageing on substrate characteristics and hydrological performance. J. Hydrol. 2017, 547, 332-344. [CrossRef]

43. Charlesworth, S. A review of the adaptation and mitigation of global climate change using sustainable drainage in cities. J. Water Clim. Chang. 2010, 1, 165-180. [CrossRef]

44. Hoang, L.; Fenner, R.A. System interactions of stormwater management using sustainable urban drainage systems and green infrastructure. Urban Water J. 2015, 13, 739-758. [CrossRef]

45. Davis, A.P.; Stagge, J.H.; Jamil, E.; Kim, H. Hydraulic performance of grass swales for managing highway runoff. Water Res. 2012, 46, 6775-6786. [CrossRef]

46. Winston, R.J.; Powell, J.T.; Hunt, W.F. Retrofitting a grass swale with rock check dams: Hydrologic impacts. Urban Water J. 2018, 16, 404-411. [CrossRef]

47. Allen, D.; Olive, V.; Arthur, S.; Haynes, H. Urban sediment transport through an established vegetated swale: Long term treatment efficiencies and deposition. Water 2015, 7, 1046-1067. [CrossRef]

48. Fach, S.; Engelhard, C.; Wittke, N.; Rauch, W. Performance of infiltration swales with regard to operation in winter times in an Alpine region. Water Sci. Technol. 2011, 63, 2658-2665. [CrossRef] [PubMed]

49. Woznicki, S.A.; Hondula, K.L.; Jarnagin, S.T. Effectiveness of landscape-based green infrastructure for stormwater management in suburban catchments. Hydrol. Process. 2018, 32, 2346-2361. [CrossRef]

50. García-Serrana, M.; Gulliver, J.S.; Nieber, J.L. Non-uniform overland flow-infiltration model for roadside swales. J. Hydrol. 2017, 552, 586-599. [CrossRef]

51. Marsh, T.; Kirby, C.; Muchan, K.; Barker, L.; Henderson, E.; Hannaford, J. The Winter Floods of 2015/2016 in the UK-A Review; Centre for Ecology and Hydrology: Wallingford, UK, 2016.

52. Ellis, J.B.; Viavattene, C. Sustainable Urban drainage system modeling for managing urban surface water flood risk. CLEAN Soil Air Water 2013, 42, 153-159. [CrossRef]

(C) 2020 by the authors. Licensee MDPI, Basel, Switzerland. This article is an open access article distributed under the terms and conditions of the Creative Commons Attribution (CC BY) license (http://creativecommons.org/licenses/by/4.0/). 